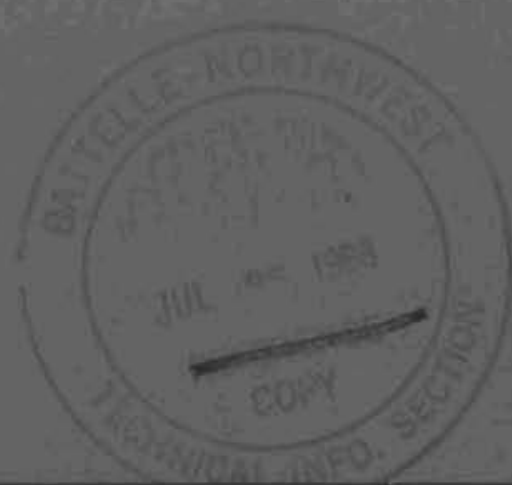

\title{
ZIRCONIUM ELECTROPLATING ON URANIUM FROM MOLTEN ALKALI FLUORIDE SALTS
}

D. A. Nissen

R. W. Stromatt

JUNE 1,1968

\section{AEC RESEARCH \& DEVELOPMENT REPORT}




\section{LEGAL NOTICE}

This report was prepared as an account of Government sponsored work. Neither the United States, nor the Commission, not any person acting on batalf of the Commission:

A. Makes ony warranty or representation, expressed or implied, with respect fo the caccuracy, completeness, or usefulness of the information contained in this report, or that the use of any information, opparatus, method, or process disclosed in this report may not infringe privately owned rights; or

B. Assumes any fiabilities with respect to the use of, or for damages resulting from the use of any informotion, opparatus, method, or process disclosed in this repori.

As used in the above, "person acting on behalf of the Commission" includes any employee or confractor of the Commission, or employee of such contractor, to the extent that such employee or con. tractor of the Commission, or emplayee of such contractor prepares, disseminates, at provides access to, any information pursuant to his employment or contract with the Commission, or his employment with such cantractor.

\section{PACIFIC NORTHWEST LABORATORY}

RICHLAND, WASHINGTON

operaled by.

BATTELLE MEMORIAL INSTITUTE

for the

UNITED STATES ATOMIC ENERGY COMMISSION UNDER CONTRACT AT(4S-1)-1830 


\section{0}

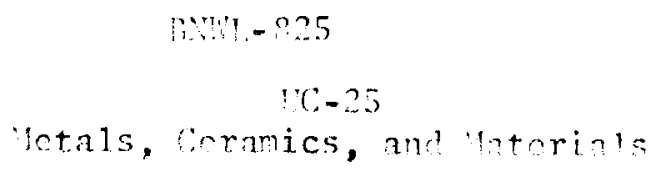

ZIRCONIUM ELECTROPLATING ON IMANIU:A

TRO' '1OLTEN ALKALI FIIIORINT: SALTS

By

D. A. Nissen*

R. ir. Stromatt

Surface and Coolant chemistry section. Chemistry and Chemical Fngincering nenartment

June 1,1968

PACIFIC NORTIINEST LABORATORY

RICHLAND, GASHINTTON

* Wow ermloyed by Sandia Corn, Albumerque, Vew lexicn. 


\begin{abstract}
T
Conditions were establishod under which zirconium could ie electroplated onto uranium from molten alkali fluoride melts. Although grod electroplates were made from several. such solvents over a fairly wide range of conditions, the best results were oltained using the VT-Lir eutectic under the following conditions: current clensity from 20 to 10 $\mathrm{mA} / \mathrm{cm}^{2}$, temperatures from 625 to $675^{\circ} \mathrm{C}$, and $\mathrm{ZrF}_{4}$ concentration from 2 to 10) wt. \%

The zirconium plates were fine rrained and non-morous un to a thickness of about $5 \mathrm{mils}$, after which isolated crystallites began to grow. It was proposed that the change in plate structure was related to chemical clanges in the electrolyte. A nothod to prevent melt degradation was proposed, and an attempt to test the method was mado.
\end{abstract}




\section{TABLE OF CONTENTS}

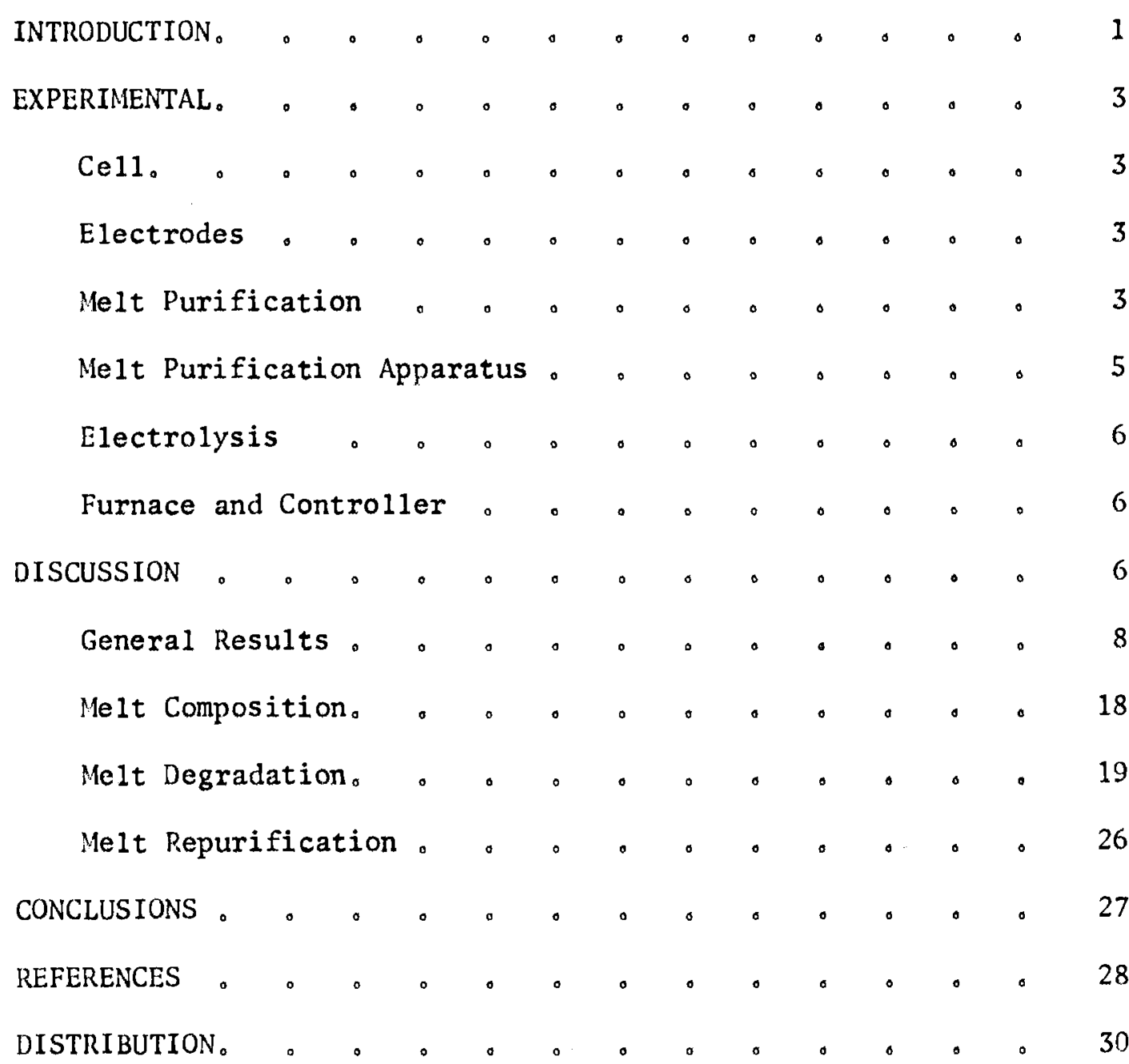




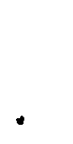




\author{
ZIRCONIU! IELTCTROPLATING ON IRANIUM \\ FRO'1:1OLTIN ALKALI FLUORIDE SALTS \\ 1). A. Nissen \\ R. i. Stromatt
}

INTRODUCTION

Interest in increasing the power density of nuclear roactors has focused attention on the ability of the fuel element cladding to withstand the more rigorous demands thus nut unon it. For this reason, notals from groups $I V-B, V-B$, or VI-B have promiso as a fuol eloment clariding material. Of these, zirconium is nerlans the most desiralle; not only because of its low neutron cross section, but also because of its corrosion resistance. (1)

zirconium is already being used as a fuel element cladding material in the form of zircaloy-2 $\left(1.5^{\circ} \mathrm{s} \mathrm{Sn}, 0.15^{\circ} \mathrm{Fe}, 0.1^{\circ} \mathrm{Cr}\right.$, and $\left.0.05^{\circ} \mathrm{Ni}\right)$. :uch of the benefit derived from the use of zirconium is nffset hy fabrication costs in cladding the uranium fuel. If some way were found to decrease this expense, use of zirconium would be more attractive. The most obvious way is to aprly the zirconium directly on the fuel element as as an electroplate. Because of the chemically active nature of zirconium metal, attempts to electrodenosit the retal from aqueous solutions have been fruitless. Nor has electrodeposition from organic solutions proven successful.

Since zirconium could not he denosited from aquens or organic solutions, attention was turned to the use of molten salt solutions. Successful production of zirconium by clectrodenosition from a mixed fluoride-chloride me1t has been reported. $(4,5)$ llowever, this work was primarily concerned with electrowimning tho metal; and conditions vero sought for wich the metal denosit was in the form of powier or large crystals which could easily be removed from the cathoile, and would he suitable for reworking. In electroplating metals, on the other hand, the desired derosit is adherent to the substrate, comosed of fine crystals, smootl, and non-porous, Intil the nublication of a series $n f$ 
payers by lellors and Senderoff there had been no successful procedures reported for the deposition of thick coherent plates of the group IV-B. $V-B$, and VI-B metals。( $6 a-d)$ This work of yellors and Senderoff is particularly important in that previous work on the electrodeposition of metals from molten salts has always resulted in the production of loose dendrites, powder or sponge; ${ }^{(7)}$ with the exception of diffusion plating for some metals. (8) It should be noted that the earlier work was done for the most part with chloride or mixed chloride-fluoride systems; and。 as Mellors and Senderoff point out, a pure fluoride salt electrolyte is essential for the production of plates. (6a) For electroplating zirconium, a LiF-KF or LiF-NaF-KF solvent was found satisfactory。 ${ }^{(6 \mathrm{c})}$ The addition of chloride to a zirconium electroplating solution caused serious deterioration of the plate. Attempts in this laboratory to electroplate zirconium from molten alkali clloride salt resulted in the production of slimes.(9)

As pointed out by $\mathrm{Ibl}$, the structure of the deposit, in simple terms, depends strongly on the rate of formation of new nuclei and the rate of growth of the crystals already present. (7) Grain size is a strong function of the ratio of these two rates. That is, if the rate of nucleation is small compared to the rate of crystal growth, a deposit with coarse grains results. In the reverse case, a fine grained deposit results. Powder formation is a liniting case in which the nucleation rate is large and the crystal growth, particulariy intergrowth, is small.

Since the formation of new crystals requires more energy than the growth of already existing ones, nucleation is enhanced by a high actio vation polarization; that is, that mart of the polarization due to the presence of an energy barrier for charge transfor at the electrode solution interface。 $(10)$ As pointed out by ilinand in his studies of the discliarge of zirconium(IV) from molten salts, while zirconium(IV) disw charges in a single step to the metal without passing through lower oxidation states, there does exist an activation overpotential attrib. utable to the decomposition of complex ions. (il) As a matter of fact, it has long been known that zirconium forms complex fluozirconates with the un $i=$ and divalent fluoride salts. (12) In addition, it has been shown from infrared spectrophotometric studies of the KF- LiFm $\mathrm{K}_{2} \mathrm{TaF}_{7}$ system that tantaluril $(V)$ forms a stable complex ion in the fiuoricle melt. (13) These 
results also showed that by changing the commosition of the solvent it was possible to change the nature of the coming inn that was fomed.

On the basis of the preceding discussion, the zirconium cloctroplating studies reported herein were confined solely to flunride snlvonts with the added restriction that the melting noint of the solvent he as low as possible. Three different solvent systems were studied: 1) lii.

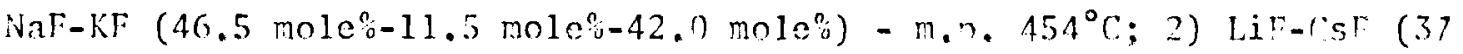

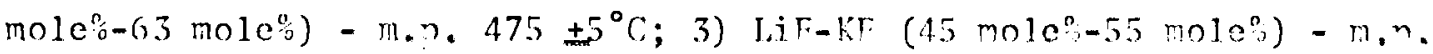
$575^{\circ} \mathrm{C.}(14)$

\section{EXPERIMENTAL}

\section{Cell}

The schematic for the ccll used for the molt nurification an! electroplating is shown in Figure 1. The coll, as shown, is set u, for nlatine. For melt purification the zirconium anode and the cathode were removon and a grantite liner was inserted into the cell hody. The nickel ton was fastened to the flange on the coll body with stainless stoel holts, and a conper gasket provilled the gas tight seal. Innel swagelnk fittings wero used to make gas tight fittings on all inlots and oxit norts.

\section{Electrodes}

The cathodes were made from conner rod and maclined from uranism fin 1 elements, and were $1-1 / 2$ inches 1 nne by $1 / 4$ incles riameter. One ond lons drilled and tamed to accent a t'ireaded $1 / 8$ inch Inconol rod. The rod was insulated from the cell by a $1 / 4$ inch nutsire dinmeter. $1 / 3$ inch inside diameter alumina slecve. The internal sleove liameter was suct that the Inconel rod made a snug slin fit, which allowed nulling tho nlatod socimon us to the argon atmosphere in the conling chamer of the lic. The commer

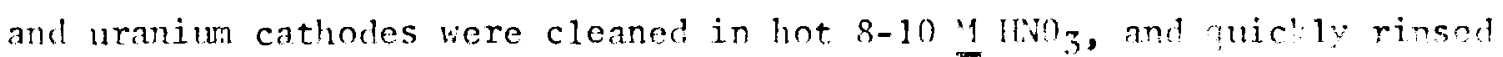
and wined dry just before they were rlaced in the cell.

The zirconium anole was formed by rollin: shoet motal into a cylindor to give a snug fit in the coll. The clectrical contact to the annde was made through the nickel coll.

Jelt Purification

leggardless of the care taken in making $w^{\prime}$ the mixture nf salts, somo 


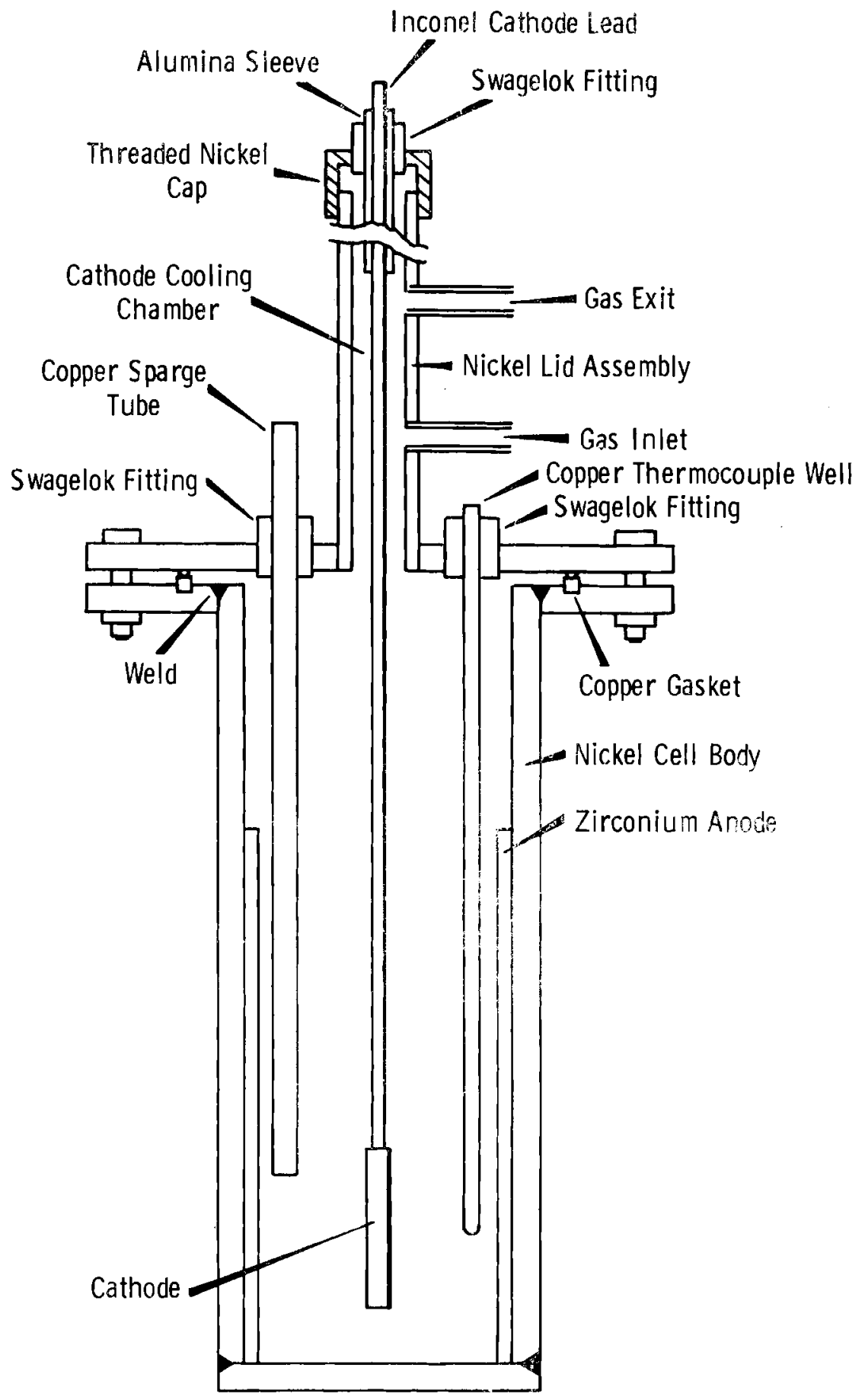

FIGURE 1

Electrolysis Cell 
water was always present. As the charge was heated, reactions could occur yielding such products as oxide, hydroxide, and peroxide ions $(15,16)$ The presence of these hydrolytic reaction products in the melt has been shown to cause poor quality, non-adherent electroplates。(6) To remove these products a technique has been reported involving an $\mathrm{HF}-\mathrm{H}_{2}$ sparge of the melt, and was used in this work。(17) It has been shown that in using this technique the oxygen content can be decreased to less than $100 \mathrm{ppm}(18)$ In some of the early experiments $\mathrm{NH}_{4}{ }^{\circ \mathrm{HF}}$ was used to provide HF through thermal decomposition. However, the HF evolution was too rapid for the technique to be successful.

In general the procedure was as follows. First, the dry chemicals which composed the electrolyte were weighed and mixed (a normal charge was usually about $400 \mathrm{gm}$ )。 The mixture was put into the graphite liner which was placed into the nickel cell. The copper gasket was put in place, the lid bolted on, and all the fittings put in place to insure a gas tight cell。An argon atmosphere (deoxygenated with an $850^{\circ} \mathrm{C}$ zirconium column) was introduced into the cell and the temperature slowly raised until the charge melted. A copper sparge tube was introduced and a $1: 1 \quad \mathrm{HF}=\mathrm{H}_{2}$ mixture was bubbled through the melt at about $650^{\circ} \mathrm{C}$ for 24 hours. The $\mathrm{HF}^{\circ} \mathrm{H}_{2}$ was purged from the melt with argon and the charge allowed to freeze. The cooled charge was removed from the graphite liner (a well purified charge slipped easily from the liner) and either stored in a desiccator or placed in the electrolys is cell.

When ready for electrolysis, the purified charge was placed ir: the gas tight electrolysis cell and heated under an argon atmosphere until molten. To remove impurity metals, the melt was held at $650^{\circ} \mathrm{C}$ and pre-electrolyzed twelve hours at $200 \mathrm{~mA} / \mathrm{cm}^{2}$ using an $1 / 8$ inch diameter Inconel rod cathode.

Melt Repurification Apparatus.

Figure 2 is a schematic of the system designed to recirculate the melt as a means of continuously repurifying it during electrolysis. This procedure is discussed in more detail in a later section, but it essentially involved pumping the melt to the HF sparge cell from where it overflowed to the argon sparge cell, then overflowed back to the electrolysis cell. Each sparge cell was a 6 inch by 1 inch inside 
diameter nickel can with a melt retention canacity of about $50 \mathrm{ml}$. The cells had flanged tops to which the nickel lids could be bolted and sealed with copper gaskets in a fashion similar to the electrolysis cell. Alumina insulators for conductivity probes were attached to the lids through monel Swagelok fittings. The $1 / 4$ inch monel gas and melt inlet and exit lines were welderl to the colls; all other connections were made with monel Swagelok fittings. The gas inlet on the gas lift for pumping the molt to the IIF sparge cell was $1 / 8$ inch monel tubing, and was welded into the $1 / 4$ inch melt 1 ift tube $1 / 2$ inch from the bottom, as shown in Figure 2. The submergence was about 5 inches and the lift about 19 inches. The chromel-alumel thermocouple TC-1 monitore? the electrolysis cell temperatures, TC-2 monitnred the melt transfer line tenperature, and $\mathrm{TC}-3$ was the control thermocouple for the sparge colls tube furnace.

\section{Electrolysis}

After the initial purification stens, the melt was roady for the planned electrolysis experiments. The cathode was inserted into the cel1, allowed to heat and finis' drying in the argon atmosnhere, and then immersed into the melt. The electrolysis was immediately starterl.

The electrolyses were run at constant current using a llarrison Lahoratories Yodel $814 \Lambda$ or Electro Product Lahoratorics indel $X$ de sumly. A :Insely 7100 , 2-pen recorder was used to record the cell voltage and current (iR drop across a known resistanco).

Furnace and Controller

A crucible type furnace controlled by either a Wheelen or a BarherColeman lodel 193C controller was used in this work. The clectrolysis melt temperature was recorded with a Yinneanolis-lloncywell notentiometric recorder from the output of a chromel-alumel thermocounle encased in a copper well inmersed in the melt.

DISCUSSION

In order to develop experimental techniques as well as judge the feasibility of zirconium plating from molten fluorides, the first work was done using copper cathodes. Copper was used initially rather than uranium because it was feared that the active nature of the uranium metal surface might induce trohlems of adherence of the zirconium nlate, 


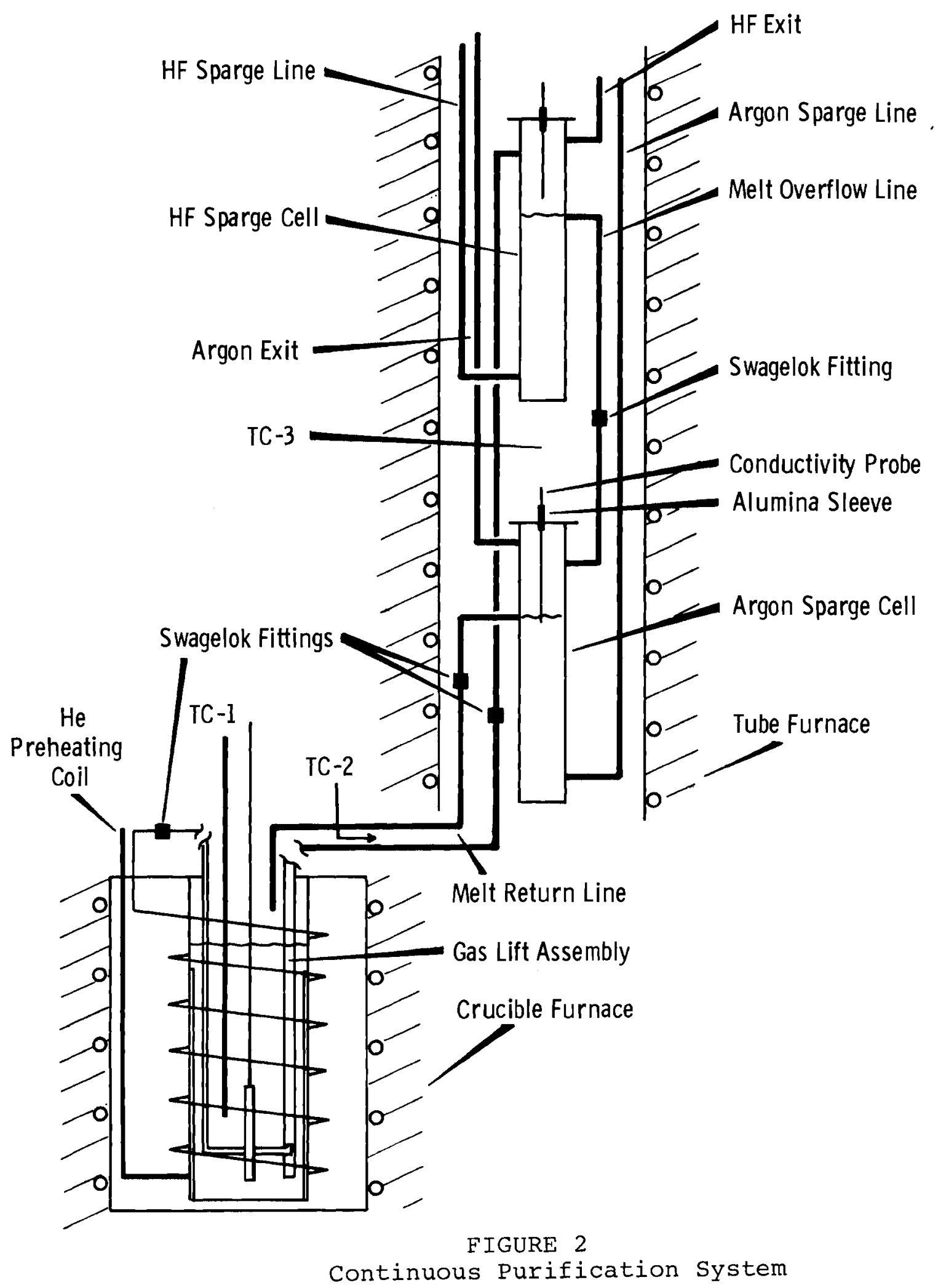


thereby making it difficult to determine proner conditions for nlatino,

After a number of experiments, tecliniques and conditions wero develoned which resulted in adherent and non-vornus zirconium eloctroplates on conper from a LiF-NaF-KF-ZrFi melt. The range of conditions of temperature, cathode current density, and zirconium(IV) concontratinn for which this was possible was also detcrmined as an aid to tire studics using the uranium cathode. The cross-section of zirconium slated conner is shown in Fighure 3 .

\section{General lesults}

IIsing uranium cathodes a large number of exneriments were conducter to determine ontimum plating conditions, and also to determino the effect of solvent composition on the nlate. Is stated carlier, three different fluoride solvent systens were studied. While it was mosible to nroluce uni form, adherent electronlates of nool quality from all three, the lit:$K F$ system seemed to yield the best rosults. In this particular solvont, the optimum cathode current density range was from $20-4 n \mathrm{~m} 1 / \mathrm{cm}^{2}$, ans! the optimum temperature range was from 625 to $675^{\circ} \mathrm{C}$. The wality of the plate did not seem to be narticularly affecter! by the zirconium(IV) concentration, at least in the rance studicd whic! ran from 2 to 10 wto. It was necessary in all cascs to keen a purified argnn atmosnlicre nver over the melt. This served, amone other thines, to loen the surface of the uranium cathode from oxilizing as it was being lowered into the nelt. Should an oxide coat form on the uranium, it could keen the zirconium "late from alhering. Figures it through s sho: examnles of the external surfaces of some electronlates and also the reninn of the interface betweon the uranium an! zirconium. These firures show tho following: The exterior of the nlate exhibits a rond donl af crystallinity, the atherence of the zirconiom olectronlate th the uranium

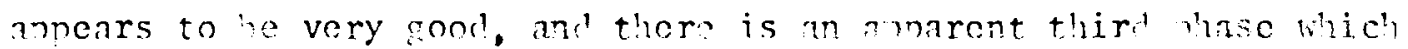
cxists betlicen the uranium and zirconium thases, whether a definite uranim-zirconium comound is formed is not lnow. llower, the zirconium-uranium phasc dingram s'ous ! solid solutinn phase with o fairly broar composition range in the resion of $70^{\circ}$ ai rennium at hout $650^{\circ} \mathrm{C}$. The niscrved third whase may be the result of that snlid solution. lilectron microprobe examinations of the interfacial roetion shome 
BNWL- 825

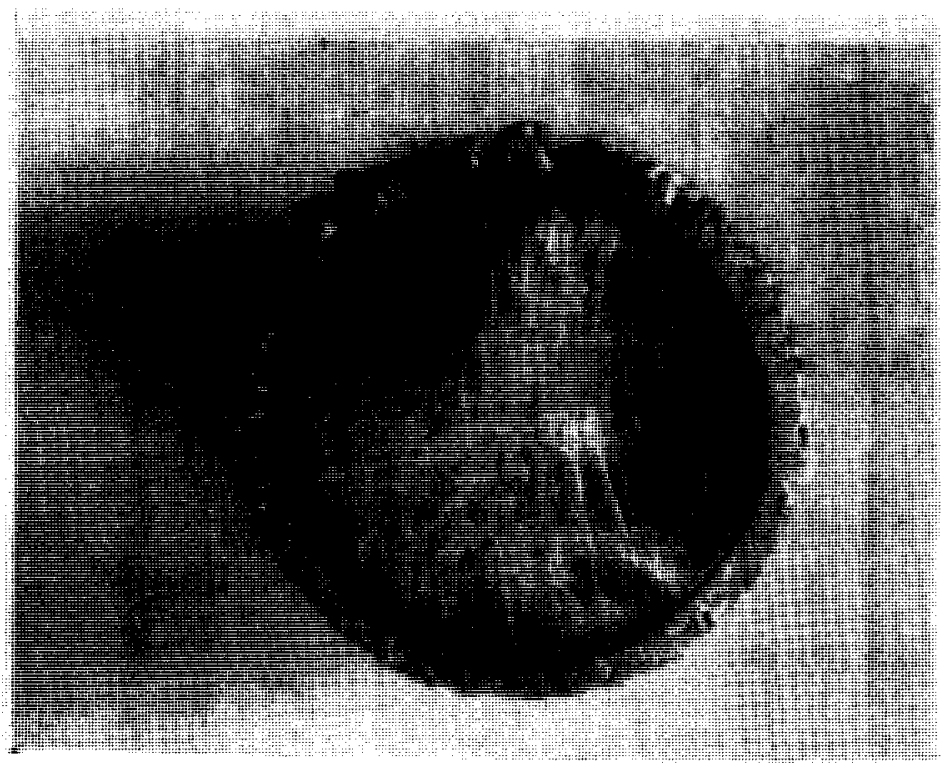

\section{Figure 3}

Cross-section of a Zirconium-plated Copper Cylinder Conditions: $T=700^{\circ} \mathrm{C}, \quad i=10 \mathrm{~mA} / \mathrm{cm}^{2}$

Electrolyte: LiF-NaF-KF + $10 \mathrm{wt}^{\circ} \mathrm{ZrF}_{4}$ 

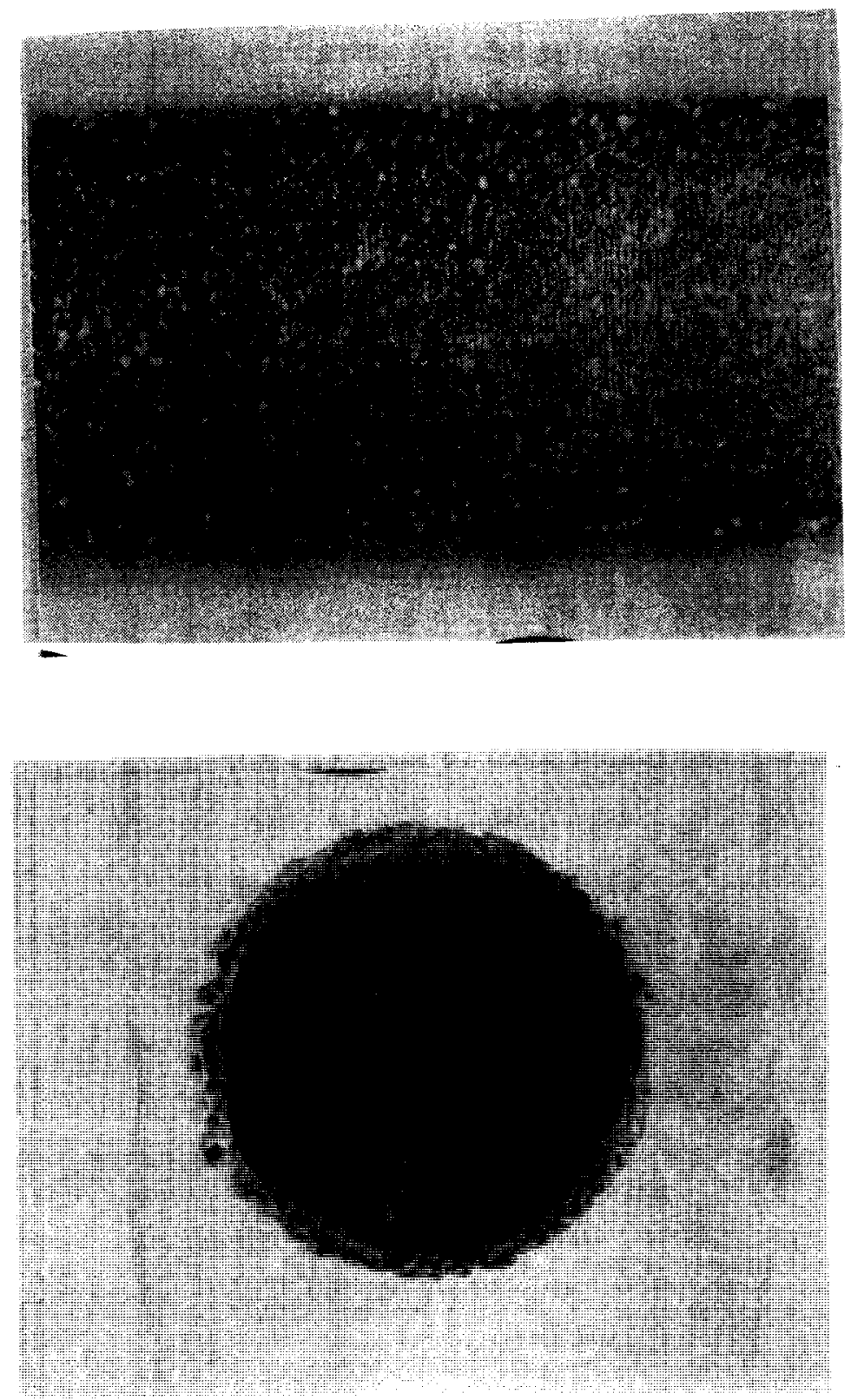

Figure 4

View of the Exterior and Cross-section Of a Zirconium-plated Vranim cylinder

Conditions: $\mathrm{T}=650^{\circ} \mathrm{C}, \quad \mathrm{i}=10 \mathrm{mM} / \mathrm{cm}^{2}$

Electrolyte: LiT-KF+ $5 w t_{0}^{\circ} \mathrm{ZrF} A$ 

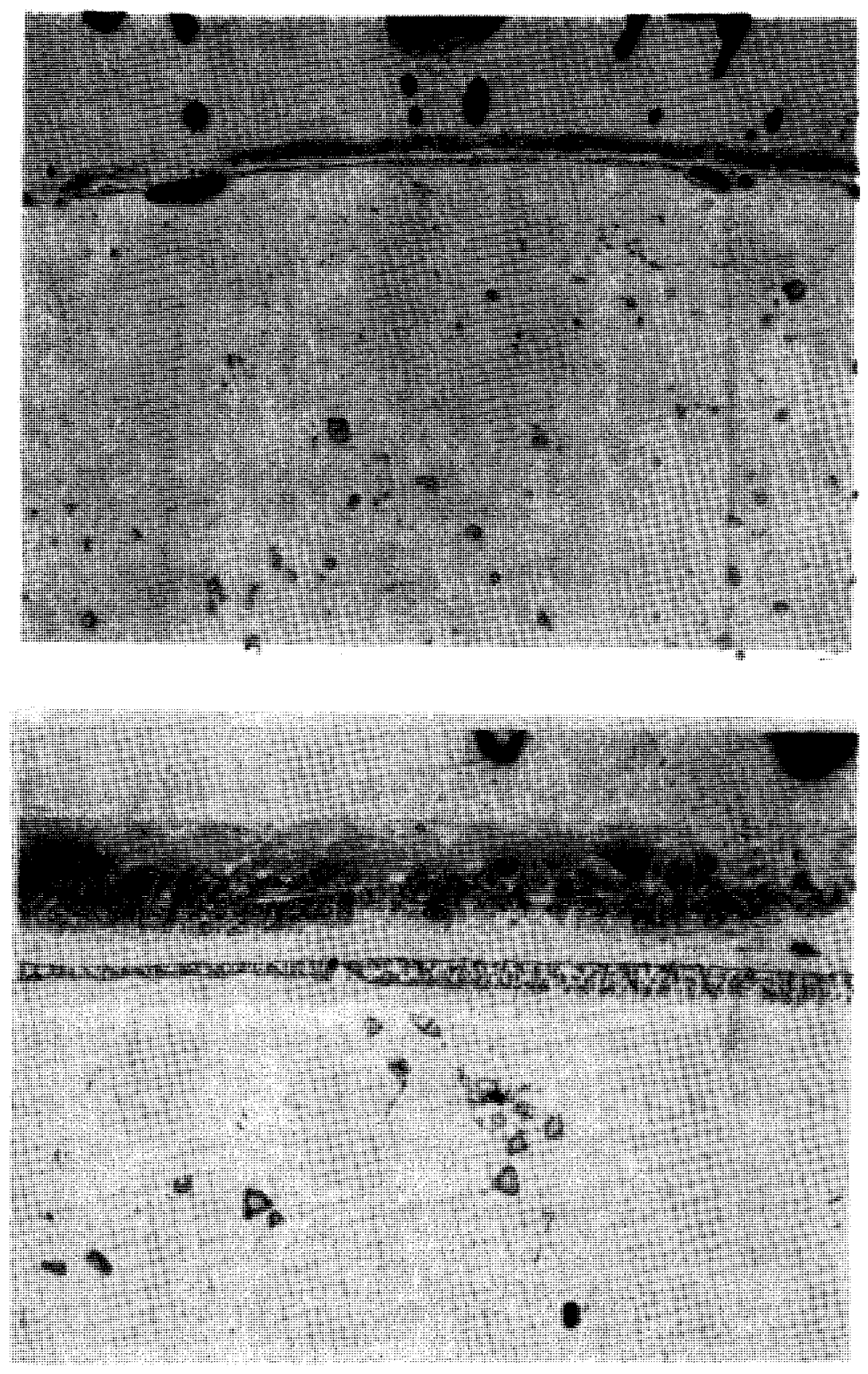

\section{Meure 5}

Photomicrograph of the Cross-section

of a zirconimmlated Uranium cylinder

Conditions: $T=650^{\circ} \mathrm{C}, \mathrm{i}=10 \mathrm{mM} / \mathrm{cm}^{2} \quad A-100 \mathrm{X}$

rectrolyte: Lit-kT+5 

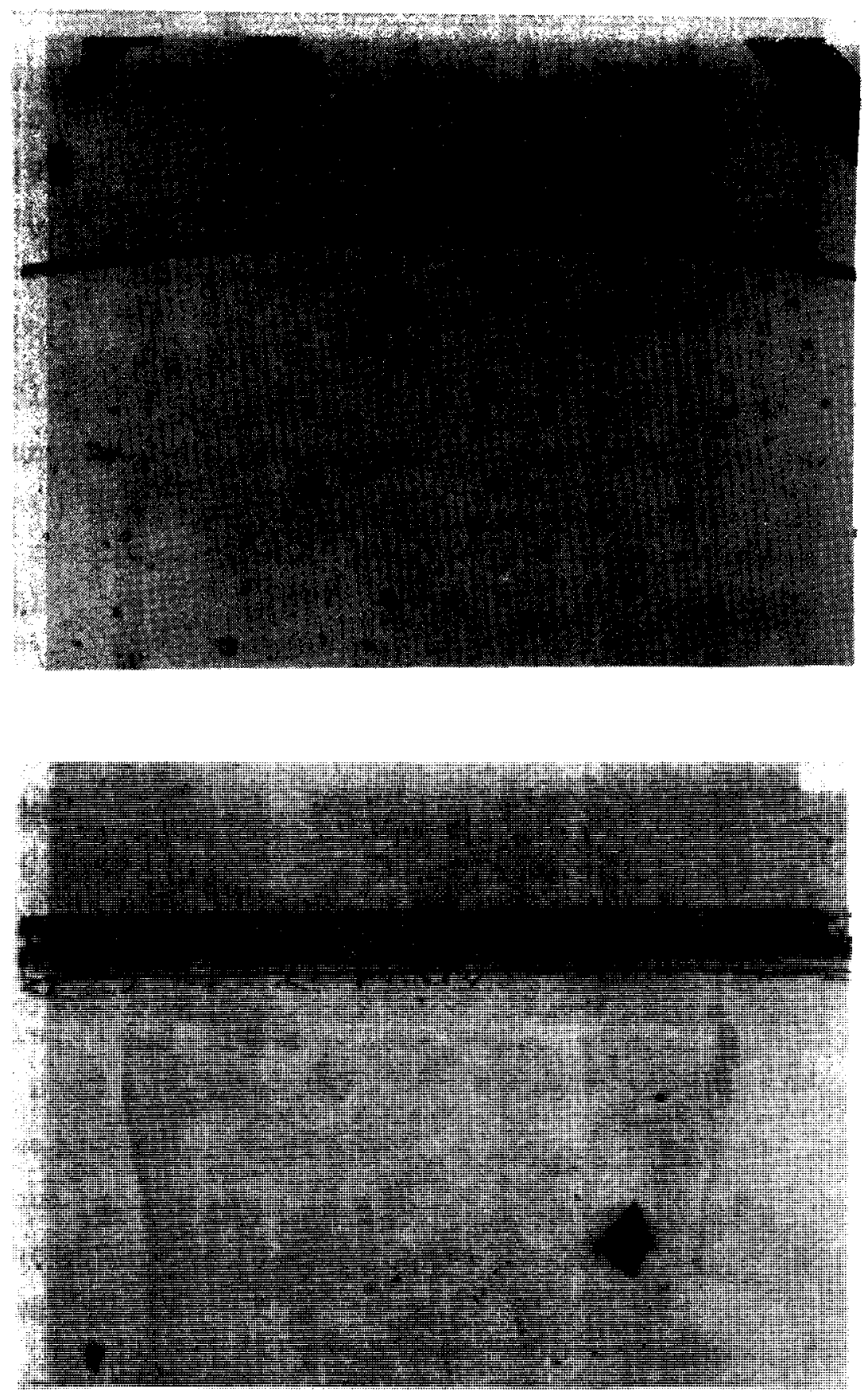

Figure 6

Photomicrographs of the frosimertion

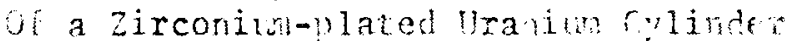

Conditions: $T-625^{\circ} \mathrm{C}, i=10 \mathrm{i}$

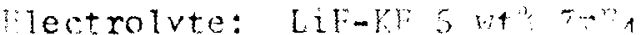



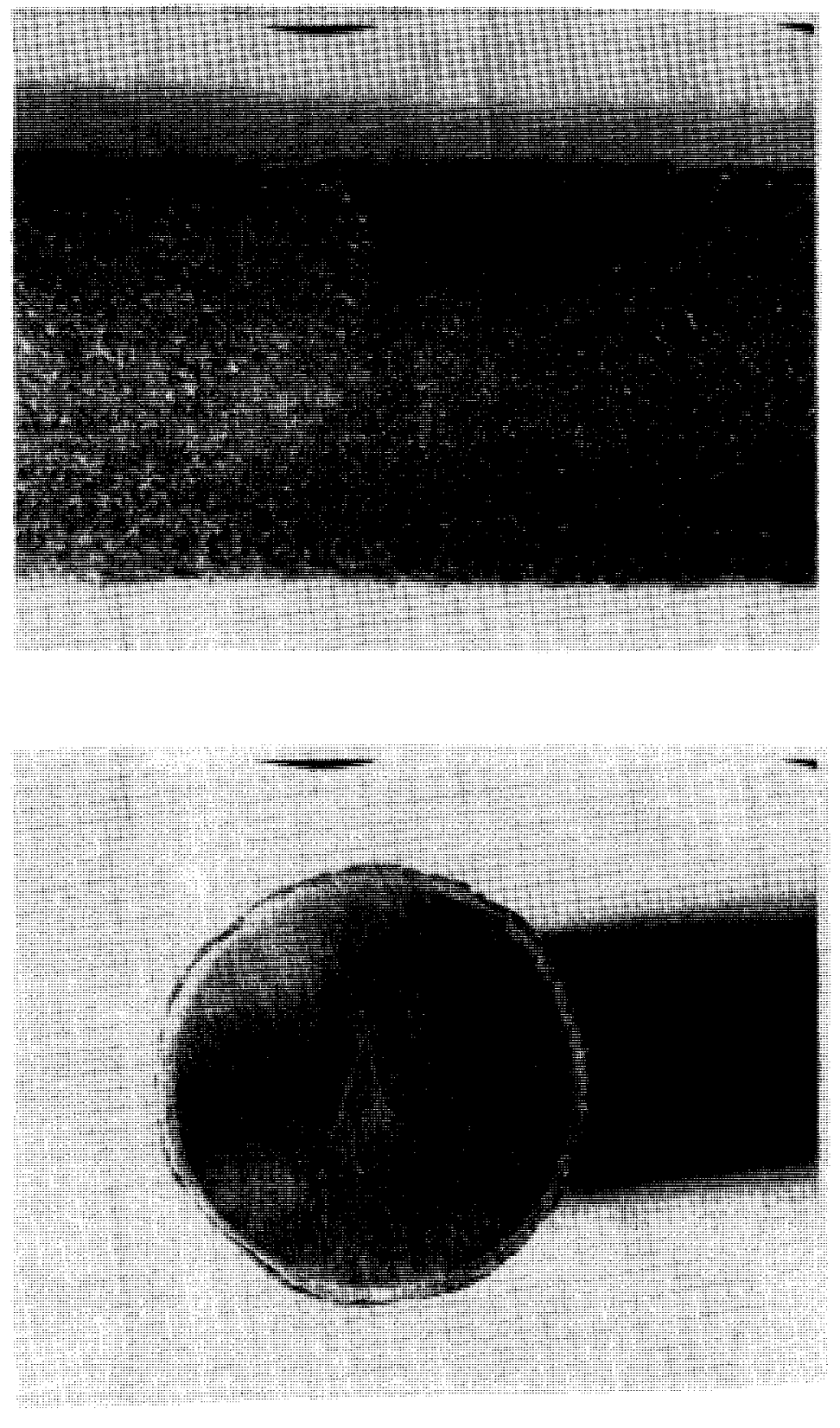

Tigure 7

View of the lixterinr and Cross-section of a Zirconjum-plated Iranium cylinger Conclitions: $T=625^{\circ} \mathrm{C}, \quad$ i $=49 \mathrm{mM} / \mathrm{cm}^{2}$

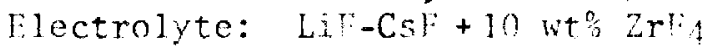



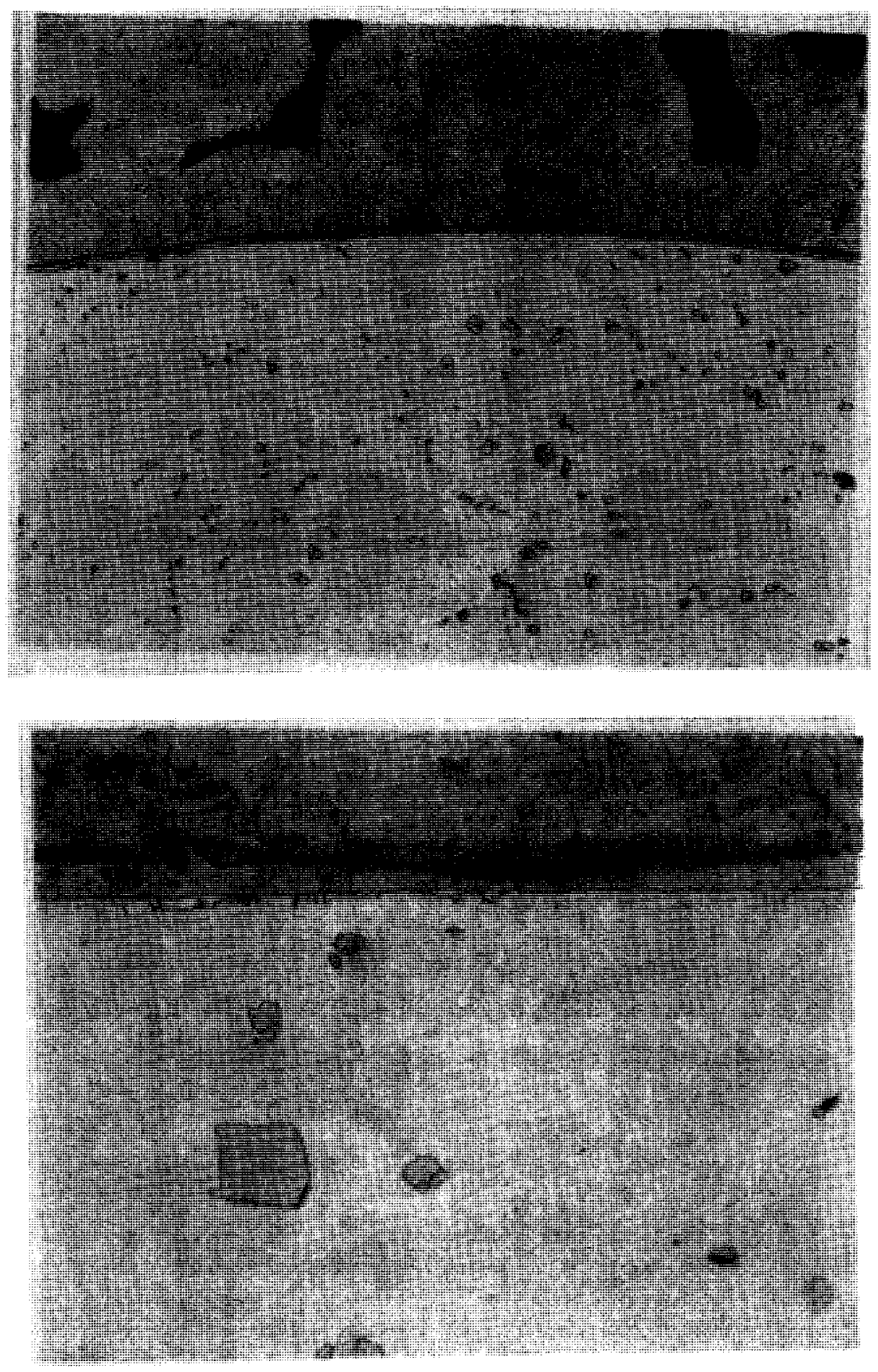

Figure 8

Photomicrograph of the Cross-section

of a Zirconium-plated Uranium Cylinder

Conditions: $T=625^{\circ} \mathrm{C}, i=40 \mathrm{mN} / \mathrm{cm}^{2}$

$A-100 x$

Electrolyte: LiF-CsT + 10 wt: $2 \mathrm{rT}_{1}$

$B-500 X$ 
only that there was interdiffusion of the two metals. On a macroscopic scale the plate appears to be non-porous, at least on the basis of immersion of the sample in concentrated HC1 with which unprotected uranium reacts vigorously. However, the photomicrographs show that the body of the plate contains voids. Apparently, the reason no porosity is indicated when the plated uranium cylinder is treated with the acid is that there is a thin layer of sound metal lying directly above the uranium, perhaps the apparent third phsse。

Careful examination of the zirconium electroplate shows that the structure of the deposit changes as a function of distance normal to the substrate. The initial portion of the plate, up to a maximum of about 5 mils, exhibits the very fine-grained, non-porous structure as shown in Figure 9. After this initial portion of the plate has been formed, a transformation in the stucture of the deposit takes place and isolated crystallites begin to grow (see Figure 10)。 In the most favorable case, the result of this type of growth is a plate with a rough surface which contains voids in the region where the crystallites began to grow independently and where there was no chance for intergrowth, ef. Figure 11。 In the least favorable situation, the isolated crystallites continue to grow in a direction normal to the uranium-zirconium interface and show no intergrowth at all, cf. Figure 13. This results in most of the zirconium being deposited in the form of 1 arge needles or very coarse crystals. These growths show little mechanical strength at the point where they join the more compact portion of the plate, and when removed they leave a depressed area in the plate. Attempts which were made to stop the selective growth of isolated zirconium crystallites by variation of melt temperature, zirconium(IV) concentration, cathode current density, or pretreatment of the uranium cathodes, were of no avail. Agitation of the melt by a stream of purified argon did seem to remedy the situation, but not reproducibly。

It should be mentioned that increasing the temperature of the electrolyte tended to promote the growth of large crystals as did increasing the initial cathode current density。 The effect of increasing the temperature was expected since an increase will generally lower the activation polarization allowing nucleation at the smaller 


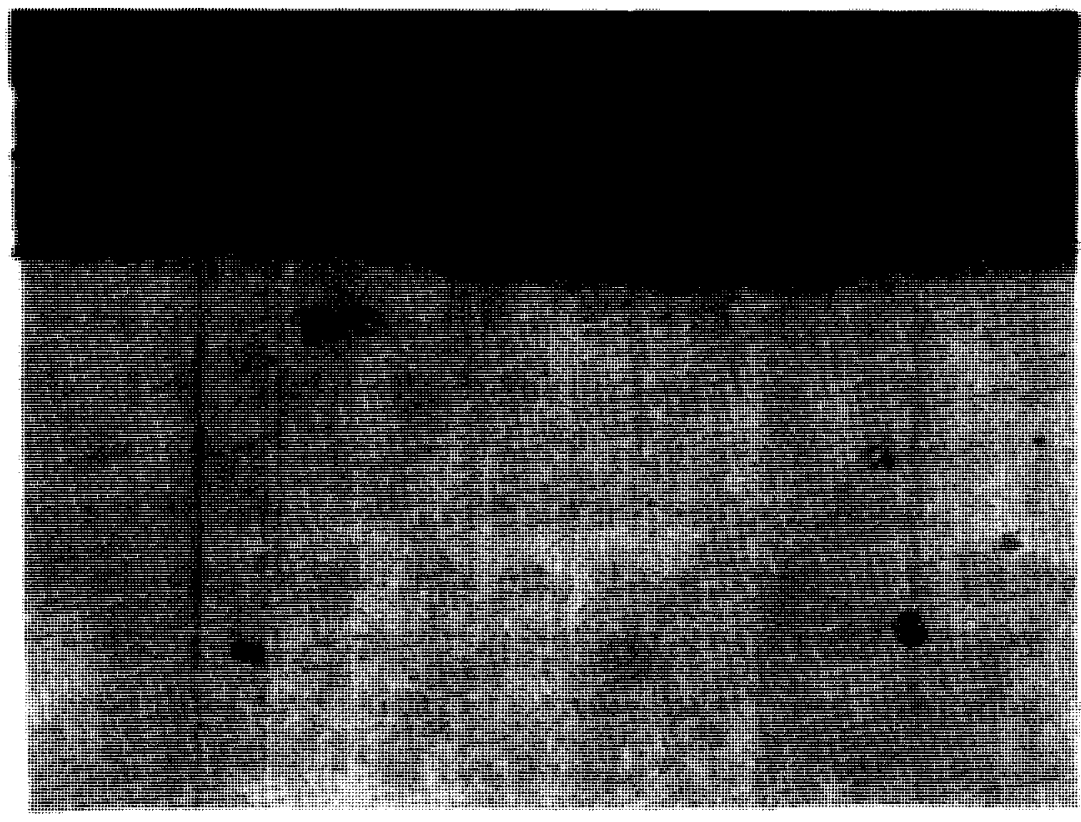

Figure 9

Photomicrographs of the Cross-section of a Zirconium-plated Iranium Cylinder

Conditions: $\mathrm{T}=800^{\circ} \mathrm{C}, \quad \mathrm{i}=10 \mathrm{~mA} / \mathrm{cm}^{2}$ Electrolyte: $\mathrm{LiF}-\mathrm{NaF}-\mathrm{KF}+10 \mathrm{wt} \% \mathrm{ZrF}_{4}$ 


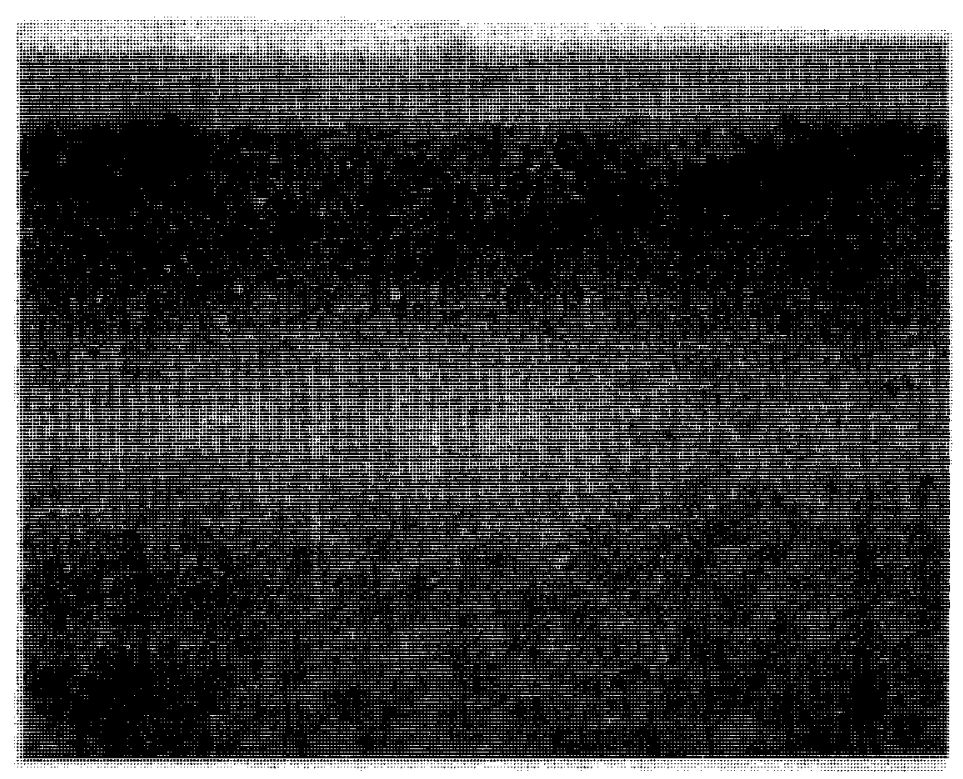

Eigure 10

View of Extemal Surface of a Zirconium Flectroplate

Conditions: $\mathrm{T}=625^{\circ} \mathrm{C}, \quad i=20 \mathrm{~mA} / \mathrm{cm}^{2}$

Electrolyte: LAF 
number of sites with a lnw energy barrier and consequently recreasing the nucleation rate. (7) On the other hand, increasing the current density usually tends to increase the nucleation rate producing more and smaller crystals. (7) linfortunately, attemnts to imprnve the plate by reducing the values of the two variables, current iensity and temperature, to their lowest nractical limits were not successful.

To date the reason for the drastic clange in crystal structure during the course of an electroplating experiment is not clearly understood. Nor is it understood why the crystal size should be larger for plates at higher current densities. These results may be related, and evidence will be presenter? further on to show the relationship between at least the change in nlate structure and the chemical changes which take place in the relt.

\section{Yelt Composition}

As mentioned earlier, the presence of an activation polarization enhances the formation of new nuclei, and one way of incrcasing the activation nolarization is by complexing the electroactive ion. On the basis of the soctronhotometric studies mentioned carlier it secmer? reasonable to assume that zirconium(IV) existed in molten fluorides as a crmplex ion; and since it was shown that the tantalum( $V$ ) comnlex could be clanged by changing, the comnosition nf the solvent, (13) it seemed reasonable to assume that the same thing could be done with zirconium(IV). It was honed that if the nroner choice of a snlvent could be made, the nucleation rate of the zirconium crystals could be enhanced and the resulting electronlate would be more uniform and free of voids.

The choice of solvents was made on the hasis of the anticinated higher fluoride activity (fluoride "donating" ahility) of lip-CsF and LiF-KF melts. That is, as the difference between the radius of the cation and anion becomes larger, the extent of molarization of the anion by the cation becomes larger and the honc' between the two becomes more covalent in nature. Therefore, as a first anmroximation, the fluoride activity of n varticular molecule increases as the size of the cation increases for the sine aninn. On this hasis, the most lilely solvent to choose, if the narameter of interest is the flunrirle 
activity, is one containing CsF.

Attempts to interpret the results of these electroplating exneriments are complicated by the existence of an unexpected chemical reaction. This reaction whose existence has been corroborated by the work of ilellors and Sencleroff, ${ }^{(6)}$ can best he formulated as

$$
41^{+}+(4+y) F^{-}+\operatorname{Zr} z 4^{\prime} 1+\operatorname{ZrF} F^{-y}(4+y)
$$

where 11 represents an alkali metal. The existence of this reaction was unexpected since reference to theoretical emf tables for the various solid and molten fluorides shows that for the two reactions of interest there is a difference in emf of about -0.7 volts. (19)

$$
\begin{array}{ll}
\mathrm{KF}+\mathrm{K}+1 / 2 \mathrm{~F}_{2} & \mathrm{I}_{600^{\circ} \mathrm{C}}^{\circ}=-4.91 \\
\mathrm{Zr}+2 \mathrm{~F}_{2} \rightarrow \mathrm{ZFF}_{4} & \mathrm{~F}_{600^{\circ} \mathrm{C}}^{\circ}=4.17
\end{array}
$$

That reaction 1 does in fact take place indicates that almost all the zirconium is in the form of an extremely stable complex ion. As a result, the LiF-CsF solvent could not he used because of its corrosion action toward the zirconium plate as is shown by reaction 1. This is supported by the observation that in order to produce a zirconium deposit it was necessary to use a cathode current density of $40 \mathrm{m \Lambda} / \mathrm{cm}^{2}$ or greater; and as the melt temperature was increased, this lower current density limit had to be increased. Furthermore, in some instances a film of corrosion product had formed underneath the zirconium plate which prevented adherence of the plate. The corrosion nroduct is, as yet unidentified; however, it is believed that it results from the reaction:

$$
4 \mathrm{Cs}^{+}+(4+y) \mathrm{F}^{-}+U=4 \mathrm{Cs}+U F^{-y}(4+y)
$$

which can occur because of the enhanced fluoride activity in this solvent, and the consequent stability of the $1 F^{-y}(4+y)$ complex inn. Melt Degradation

Throughout the numerous experiments that compose this electroplating study, the feeling was prevalent that the ressons for the structural changes which took nlace in the zirconium denosit were 
chemical in nature. Additional weight was lent to this viewpoint by: 1) within reason, changes in the cathode current density seemed to have no real effect on the structural changes which coll place in the plate; 2) the longer a particular melt was used, the coarser crystals in the plate became; and 3 ) the color of a frozen me 1 sample changed from white to a brown-black during the course of the electrolyses. Attempts to identify the cause of the color change by $x$-ray analysis of melt samples indicated that it was due neither to an increase in the zirconium salt concentration nor to the intraduction af impurities into the melt. It was discovered, however, that the color change which took place could be reversed by passing HF through the melt.

In order to determine definitely whether or not the structural changes in the zirconium electroplate were the result of changes taking place in the melt over a period of time, an experiment was conducted in which the temperature of the melt, cathode current density, and zirconium(IV) concentration were held constant while a definite number of coulombs were passed. The uranium cathode was removed from the melt, a new one inserted, and the process repeated. In each case, the uranium cathode was pretreated exactly the same way to insure that its surface was as reproducible as possible. In this way, it was hoped that should there be any substrate effects, they would be the same for each cathode. The results of these experiments are shown in Figures 11 through 13 .

It is quite obvious from examination of these results that the structure of the deposit changed rather markedly during the series of electrolyses. This supports our hypothesis that changes in the nature and/or composition of the melt were taking place during the course of these experiments, and thus it is the chemistry of the electrolyte which plays a decisive role in determining the structure of the deposit. It is less obvious what chemical changes occur which influence the structural changes in the plate. However, we do know that the changes which take place in the melt must do so over an extended period of time by virtue of the fact that a given electroplate was of better quality than the one immediately succeeding it (Figures 11 through 13). We were also able to make qualitative correlation 

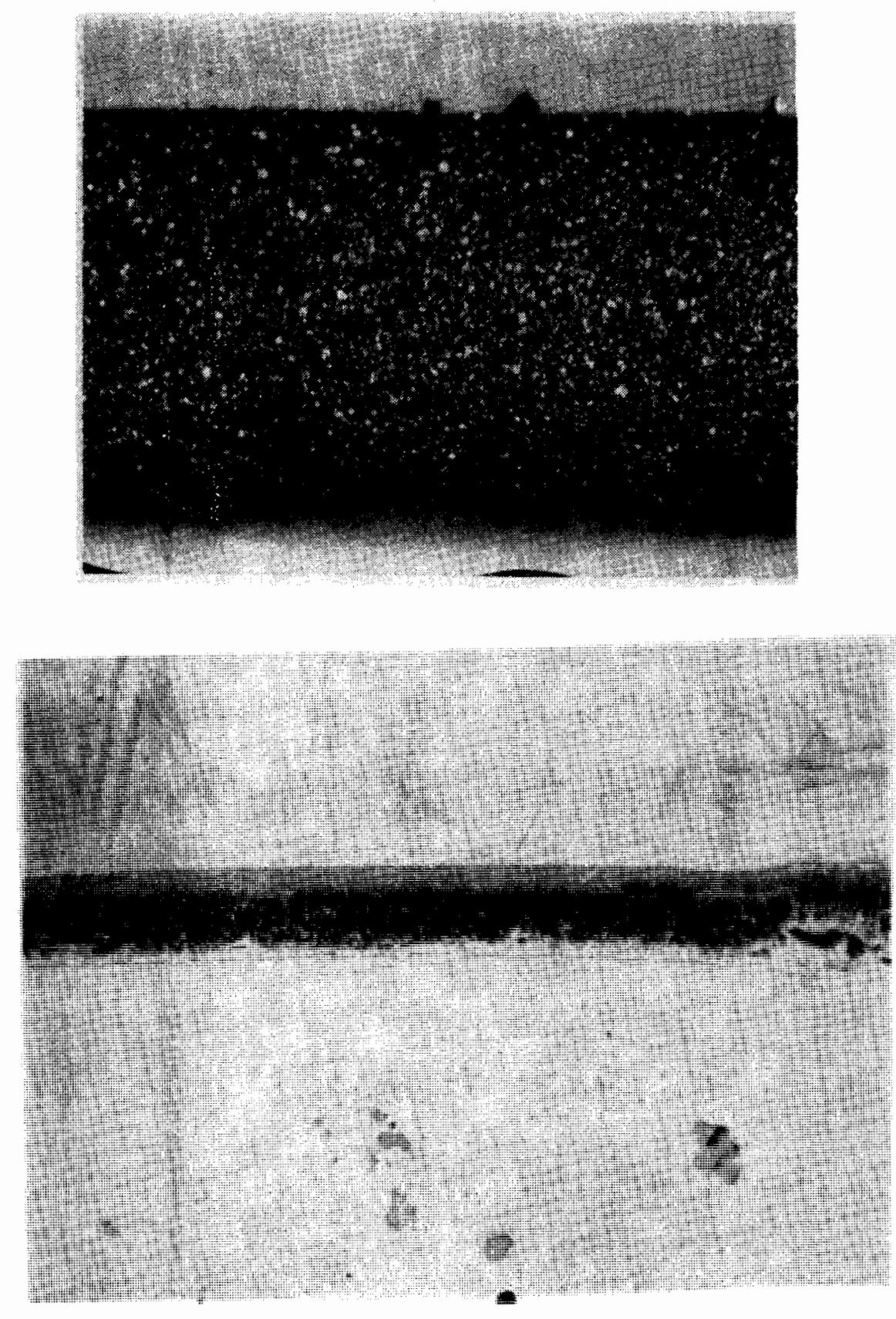

viare 11

External Surface and Crossusection of the First liectronlate (I)

Conditions: $T=625^{\circ} \mathrm{C}$, i) $=\mathrm{m} / \mathrm{co}^{2}$ for $3.210^{3}$ Coulombs;

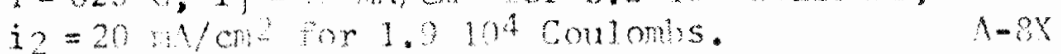

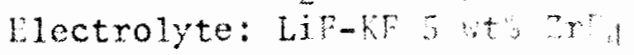

$3-500 x$ 
BNWL-825
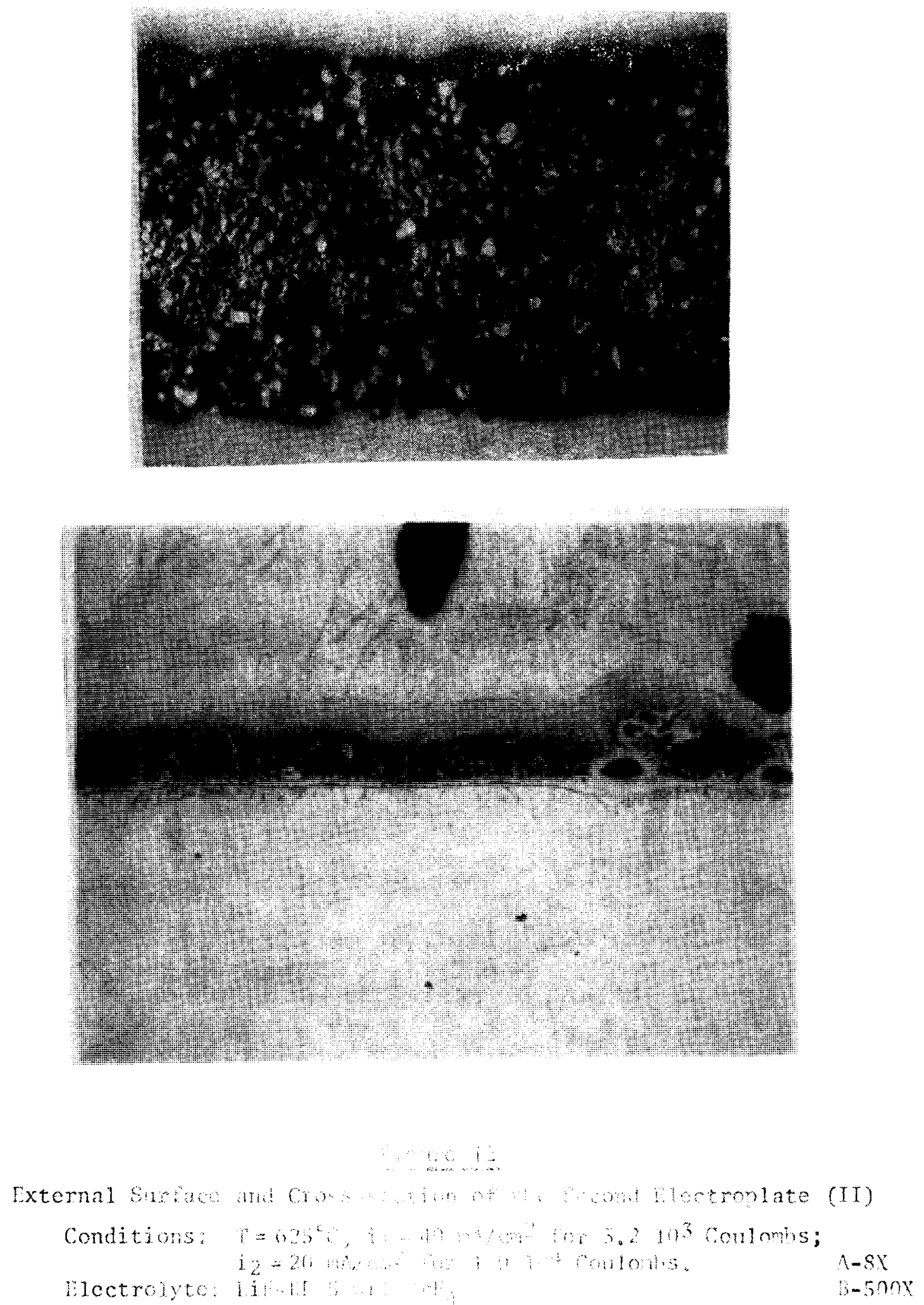

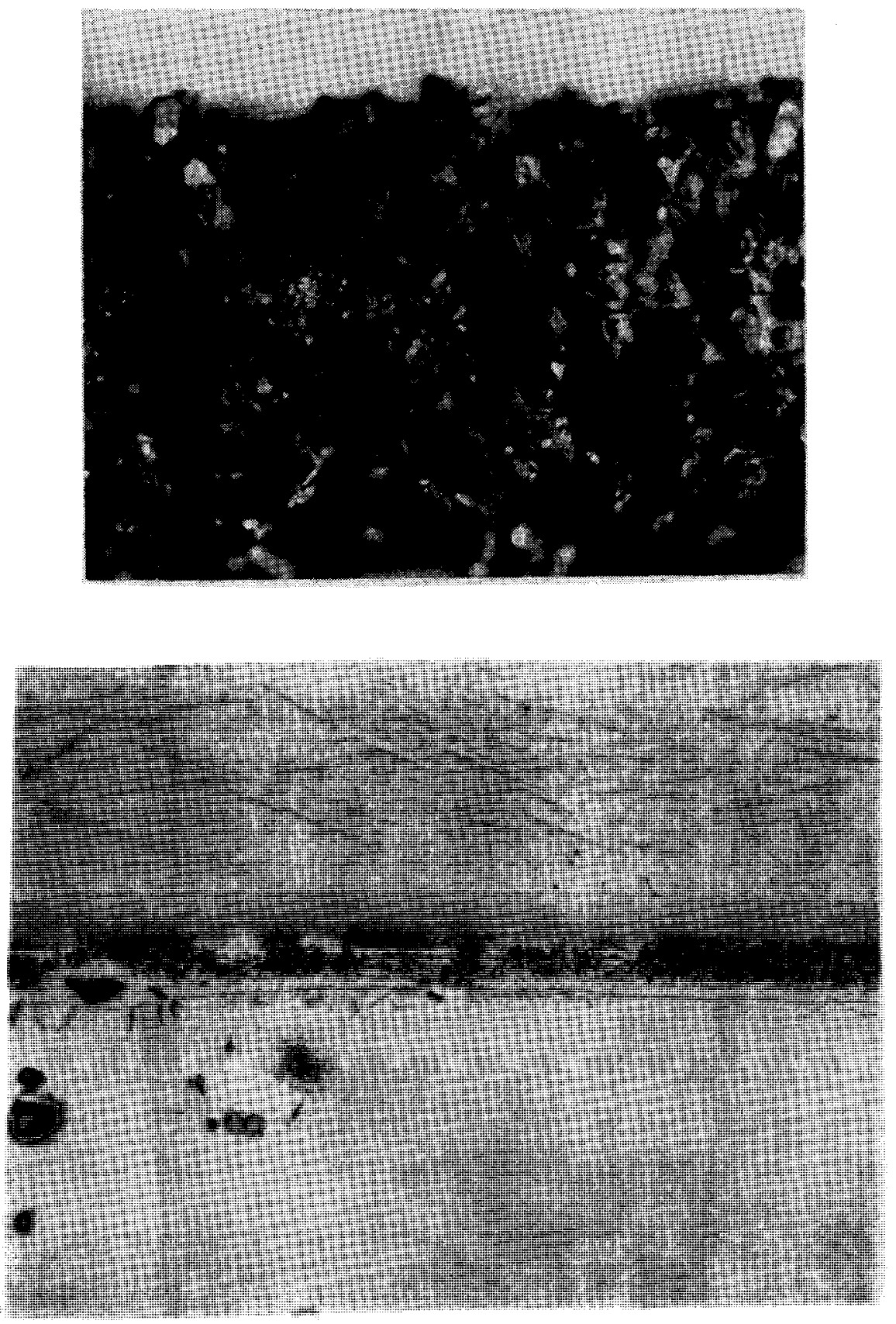

Figure 13

External Surface and Cross-section of the Third liectrontate (III)

Conditions: $T=625^{\circ} \mathrm{C}, i_{1}=10 \mathrm{~m} / \mathrm{cm}^{2}$ for 3.2103 Coulombs; $\mathbf{i}_{2}=20 \mathrm{~mA} / \mathrm{cm}^{2}$ for $1.910^{4}$ Coulomins, $1-8 \mathrm{X}$

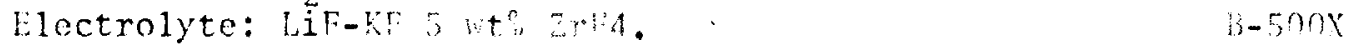


between the changes in the structure of the electroplate and the changes in the color of the frozen melt samples.

One possible explanation for these results and those shown in Figures 11 through 13 is that the changes in the structure of the electroplate were due to an air leak into the electrolysis cell. It has been shown by Mellors and Senderoff that the presence of oxygenated species in the melt can cause a serious deterioration of the plate. ${ }^{(6)}$ However, this explanation seems unlikely in view of the precautions taken to purify the argon used as an atmosphere and sparge gas in the cell plus the fact that the cell was at a slightly positive pressure. Our work has shown that the oxygen which is present either in the atmosphere above the melt or in the melt itself will cause a zirconium electroplate to lose its adherence and only upon addition of a rather large amount of oxygen in the gas cover was plate deterioration noted. In this case, a powdery deposit resulted which had very little coherence. Furthermore, the photomicrographs of the zirconium-uranium interface shown in Figures 11 through 13 indicate excellent adherence of the zirconium electroplate in addition to a lack of large concentrations of voids throughout the entire series of experiments. Finally, it is doubtful that the presence of oxygen or any oxygen-containing species would cause the observed color changes in the melt samples.

Ivanovskii and Petenev have shown in an investigation of the cathode deposits obtained by electrodeposition of zirconium from a mixed fluoridechloride melt that addition compounds of the type $\mathrm{MZrF}_{4}(\mathrm{M}=\mathrm{Na}$ or $\mathrm{K}$ ) were formed on the cathode. ${ }^{(20)}$ Such a precipitate on the cathode during the zirconium deposition could cause a large decrease in the nucleation rategrowth ratio, which in turn could result in an altered deposit.

On this basis, the following scheme is tentatively proposed to explain the change in the structure of the zirconium plate during deposition. During the course of the electrolysis, a small amount of zirconium(III) may be produced by the reaction:

$$
\dot{Z r}(I V)+e^{-}=\operatorname{Zr}(I I I)
$$

While zirconium(III) is unstable and tends to disproportionate to zirconium(IV) and zirconium metal, ${ }^{(21)}$ the complexing properties of 
the fluoride solvent may increase the stability of zirconium(III) according, to the reaction:

$$
\operatorname{Zr}(\mathrm{III})+4 \mathrm{~F}^{-}=\mathrm{ZrF}_{4}^{-}
$$

Consequently, after some period of time, the solubility product of the zirconium(III) addition compound could be exceeded and a precipitate formed. It is this precipitate, either susnended in the melt or formed at the cathode (the zirconium(III) concentration would be greatest here), which may be responsible for the drastic changes in the zirconium plate structure. That is, the precinitate may provide low energy nucleation sites with a low energy barrier, thus reducing the number of sites and promoting the growth of large crystals.

It is probable that the zirconium(III) caused the darkening of the melt samples since lower oxidation states of ions are known to do so. (22) llowever, we were unable to obtain voltammetric evidence (by polarography and chronoptentiometry) for the presence of zirconium(III), and other investigations have indicated that zirconium(IV) is reduced directly to zirconium. $(6,11,23)$ ^ possible explanation for this seeming discrepancy would be that the reduction potential for reaction 3 lies close to the reduction potential for the metal denosition, and consequently the voltammetric experiments could not resolve the two reduction nrocesses. In addition, the reducing condition in the melt brought about by the $1 \mathrm{nng}$ term uninterrupted electrolysis is conducive to the formation of species of lower oxidation states.

The fact that it is nossihle to reverse the color change of the melt samples by sparging the melt witil IF can be explained by the reaction:

$$
\mathrm{YZ} \mathrm{rF}_{4}+\mathrm{yF}^{-}+\mathrm{HF} \rightarrow \mathrm{ZrF}-\mathrm{y}(4+\mathrm{y})+1 / 2 \mathrm{H}_{2}()
$$

That is, LIF oxidizes the zirconium(III). This suggests that the melt. could be repurified using an $H F$ sparge. To test this, a melt producing poor quality plates was sparged with IIF, and then with argon to remove the HF. The electronlate producer from this melt was considerably inproved; the gross crystallinity had heen largely replaced 
with a smoother surface. IJowever, the influence of reaction 1 on the plate is not known, thus alaking a straightforward interpretation very difficult at this time.

\section{Melt Repurification}

That we could reverse the melt degradation with HF led us to two approaches to maintain good plate quality. The first was to treat the electrolysis solution directly with IF during the plating operation. This was unsuccessful because of severe hydricie formation with both the zirconium and uranium. The second was to continuously circulate the nelt through purification cells where the IfF treatment could be Inade and the IIF removed frow the melt before returning the melt to the electrolysis cell. Figure 2 shows the schenatic of the apparatus for this systen:

The melt was pumped by ass lift trori the electrolysis cell to the IIF sparge cell. The overflow from this cell was gravity fed to the argon sparge cell. Finally the melt overfiow from the argon sparge cell was retumed to the electrolysis cell by a gravity feed. As shown in Figure 2, the portion of the melt transfer lines near TC-2 was ontside of the furnaces. In order to prevent the nelt from freezing there, it was found necessary to wrap the lines vith auxiliary lestexs. In addition, the melt flow appoared to be more dependable using helim rather than argon as the gas lift, probally because the helium was easier to preheat. Under these conditions it was easy to maintair meit flow at approximately $30 \mathrm{mi} / \mathrm{min}$ with a helium fiow of about $200 \mathrm{mi} / \mathrm{min}$. A melt flow of about $60 \mathrm{ml} / \mathrm{min}$ could be obtained with little more difficulty。

In order to determine if the melt were flowing properly, the follow ing method was used. A conductivity probe in the llF cell was set so that it detected an overflow. A conductivity probe in the argon cell made contact when the melt was just helow the overflow level. In addition, a thermocouple placed at TC-2 indicated melt flow by a rise in temperature. The heaters for this section were regulated at about $500^{\circ} \mathrm{C}$, the electrolysis cell melt was 625 to $675^{\circ} \mathrm{C}$ and the melt in the purification cells about $700^{\circ} \mathrm{C}$. 
During the first plating run a leak nccurred somewhere in the purification section. Because the furnace was plugged at both ends with insulation, most of the fluoricle salt vapor remained in the furnace interior. This combination of air, salt vapor, and temperature was very corrosive to the nickel and monel components; and the entire purification system was corroded beyond repair. It was not possible to detect the location of the primary failure.

Although the project was teminated at that time, we fecl that, because of the successful initial operation of the recirculating system, the continuous purification system can be made to work. The nurification section would be simplified by eliminating the conductivity probes and minimizing the number of Swagelok connections. Thermocouple probes can detect if the melt is flowing, and the basic design of the system is now good enough to eliminate the need for the versatility afforded by the Swagelok connections.

\section{CONCLUSIONS}

We have demonstrated that under anpronriate conditions it is nossible to produce a high quality, non-norous atherent zirconium electroplate directly onto uranium from alkali fluoride melts. llowever, the chemistry of the electrolyte itself plays a decisive role in determining the structure of the deposit. In order to control the quality of the me1t, a continuous purification system was incorporated in the apparatus. Before this schene could be proven, a leak in the purification system occurred and the subsequent corrosion destroyed the apparatus.

Although we feel that maintaining the purity of the melt will he1p maintain the quality of the plate, we have not demonstrated this. Nor are we certain that this is the correct approach. Consenuently, before further development on zirconium electroplating is continued, a more fundamental program should he carried out towarl understanding the chemistry and electrochemistry of zirconium inns in the molten alkali fluoride solvent. 


\section{References}

1. G。 L。 Miller, Zirconium, Academic Press, New York, N。Y., 1954。 1st Edition, pp。203-205。

2. W。 E。 Bradt and $H_{0}$ B。 Linford。 "The Electrolysis of Aqueous Solutions of Sodium and Zirconyl Sulfates," Trans.Electrochem。 Soc. 1936 。

3. M。N.Holt。 "Attempts to Electrodeposit Zirconium," J。Electrochem。 Soc. 98, 33C。1951。

4. M。A。 Steinberg, $M_{0} E_{0}$ Sibert, and E。 Wainer。 Zirconium and Zirconium Alloys, Amer。Soc。 Metals, Cleveland, Ohio, 1953, pp。37-72。

5. $M_{0}$ A。 Steinberg, $M_{0} E_{0}$ Sibert, and $E_{0}$ Wainer。 "Extractive Metallurgy of Zirconium by the Electrolysis of Fused Salts II Process Development of the Electrolytic Production of Zirconium from $\mathrm{K}_{2} \mathrm{ZrF}_{6}$, " J. Electrochem。Soc.

6. G。 W。 Mellors and So Senderoff。 "Electrodeposition of Coherent Deposits of Refractory Metals," (a) "I。Niobium," $\mathrm{J}_{0}$ Electrochem。 Soc。 112 , 266 (1965); (b) "II The Electrode Reaction in the Deposition of a Tantalum," J。Electrochem。Soc, 112, 841 (1965); (c) "III Zirconium," J。Electrochem。Soc, 113, 60 (1966); (d) "IV The Electrode Reactions in the Deposition of Niobium," $J_{0}$ Electrochem, Soc., 113, 66 (1966)。

7. N. Ibl。 "Applications of Mass Transfer Theory: Formation of Powdered Metal Deposits," Advances in Electrochem。 and Electrochemical Engineering, edited by Paul Delahay, Interscience Publishers, New York, 1963. Vol。2, p。49。

8. NoC。Cook, F。 A。 Fosnocht, and J。D。Evans。 "The Alloying of Metal Surfaces in Molten Fluorides," Proceedings of the 1968 Conference National Association of Corrosion Engineers, Cleveland, Ohio。

9. D。A。 Nissen and $T$ 。 $S$ 。 Soine. Unpublished data。

10. NoIb1。 "Applications of Mass Transfer Theory: Formation of Powered Metal Deposits," Advances in Electrochem。 and Electrochemical Engineering, edited by Paul Delahay, Interscience Publishers, New York, 1963。 Vo1。2, p。69。

11. R。 Winando "Etude Mechanisms D'Electrode Lors de L'Electrolyse de Melange Fondus MaCl-ZrF 4 ," Electrochemica Acta, 7, 475。1962。

12. HoL。 Wells and $H_{0} W_{0}$ Foote. "Double Fluorides of Zirconium with Sodium Lithium and Thalium," Amer. J。Science, 3, 46. 1897.

13. J。S。Fordyce and $R_{0} L_{0}$ Braun。 "Infrared-Reflection Spectra of Molten Fluoride Solution: Tantalum (V) in Alkali Fluorides," $J_{0}$ Chem。Phys., 44, 1159。1966。 
References (Continued)

14. Phase Diagrams of Nuclear Reactor Materials edited by R.E.Thoma。 ORNL -2548 Oak Ridge National Laboratory, Oak Ridge, Tennessee。 November 1959。

15. CoF。Baes。 The Chemistry and Thermodynamics of Molten Salt Reactor Fluoride Solutions SM-66/60, Oak Ridge National Laboratory, Oak Ridge。 Tennessee。

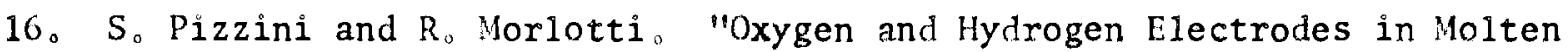
Fluorides " Electrochemica Acta, 10, 1033。1965。

17. R。B。Briggs。 Molten Salt Reactor Program Semiannual Progress Report. OWNL $\infty 3626$ pp。 $137-14$, Oak Ridge National Laboratory, Oak Ridge Tennessee, January 1964 。

18. $F_{0} A_{0}$ Doss, $J_{0} E_{0}$ Forgan and $J_{0} H_{0}$ Shaffer。 "Fluoride Sait Production," Reactor Chem。Division Annual Progress Report, ORNL-3262, pp。27-28。 Oak Ridge National Laboratory, Oak Ridge, Tennessee, January 1962 。

19. Wo J。 Hamer, $M_{0} S_{\circ}$.MaImberg and $B$, Rubin。 "Theoretical Electromotive Forces for Cells Containing a Single Solid or Molten Fluoride, Bromide。 or Iodide." J.Electrochen。Soc ${ }^{\circ}$ 112,750。1965。

20。 $\mathrm{L}_{\circ} \mathrm{E}_{0}$ Ivanovskii and $\mathrm{O}$ 。 $\mathrm{S}$ 。Petenev。 "Some Processes in Cathodic Deposition of Zirconium from ChloridemFluoride Melts,"Tr。 Inst。 Elektrochim。Akad, Nauk,SSR Mal'sk Filal, No。2,71。 1961。

21. "Thermodynamic Properties of the Halides" Paper 6 in National Nuclear Energy Series IV, Volo 19B, Chemistry and Metallurgy of Miscellaneous Materials: Thermodynamics by L。 L。 Quillo McGraw Hili Book Co。 Inc New York。 $\mathrm{N}_{0} \mathrm{Y}_{0} 1950 \% \mathrm{p}_{0} 76$ 。

22. Jo D. Corbett. "The Solution of Metals in Their Molten Salts,"Fused Saits, edited by $B_{0}$ Sundheim。 McGraw-Hill Book Co。, Inc。s New York。 $\widehat{N_{0} Y_{0}}, 1964, p_{0} 341$ 。

23. D。 L。 Manning and Gleb Manantov, "Current-Voltage Curves for Zirconium and Uranium in folten Fluorides " J。 Electroanal。Chem ${ }^{\circ}, 6,328.1963$. 
DISTRIBUTION

Onsite

\begin{tabular}{c} 
Copy Number \\
\hline 1 \\
2 \\
3 \\
4 \\
5 \\
6 \\
7 \\
8 \\
$9-18$ \\
10 \\
11 \\
$12-16$ \\
$17-18$
\end{tabular}

$19-20$

21

Offsite
Battelle-Northwest

$\Lambda$ 。 $L$ 。 Bement

$\mathrm{D}$ 。 $\mathrm{R}$ 。 de Halas

R。 L。Dillon

E. A。 Evans

B. Griggs

J。 No Judy

$J$ 。 $R$ 。 Lundquist

A。 Mo Platt

R。 Wo Stromatt

$\mathrm{J}$ 。C 。 Tverberg

$\mathrm{R}$ 。 $\mathrm{E}$ 。Westerman

Technical Information Files

Technical Publications

Douglas United Nuclear

Milton Lewis

$\mathrm{AEC}, \mathrm{ROO}$

C。 L。 Robinson

AEC, Chicago Patent Group

G. Ho Lee

R。 $K$ 。 Sharp

AEC, DTIE

UC-25 Distribution

Battelle Memorial Institute 